\title{
Blockade of the oestrogen-induced LH surge in the ovariectomized common marmoset (Callithrix jacchus) by an LHRH antagonist
}

\author{
K. T. O'Byrne, S. F. Lunn and H. M. Fraser \\ MRC Reproductive Biology Unit, Centre for Reproductive Biology, 37 Chalmers Street, \\ Edinburgh EH9 $3 E W, U K$
}

\begin{abstract}
Summary. Six long-term ovariectomized adult marmoset monkeys were treated at $0 \mathrm{~h}$ with $35 \mu$ g oestradiol benzoate s.c. to induce an LH surge. They were also treated with detirelix (an LHRH antagonist) at $0 \mathrm{~h}, 12 \mathrm{~h}$ and $24 \mathrm{~h}$ (Exp. 1), or at $0 \mathrm{~h}$ and $24 \mathrm{~h}$ (Exp. 2) at a dose of $300 \mu \mathrm{g} / \mathrm{kg}$ s.c., or received the detirelix vehicle alone at $0 \mathrm{~h}, 12 \mathrm{~h}$ and $24 \mathrm{~h}$ (Exp. 3). All animals received the three treatments, with at least 4 weeks between experiments. Blood samples were collected at $0 \mathrm{~h}$ and at $6-12 \mathrm{~h}$ intervals for $72 \mathrm{~h}$ after oestradiol for the determination of plasma $\mathbf{L H}$ by bioassay. In control animals, oestrogen treatment resulted in a decline in plasma $\mathrm{LH}$ from $30.0 \pm 5.8$ at $0 \mathrm{~h}$ to $12.8 \pm 2.6 \mathrm{ng} / \mathrm{ml}$ at $6 \mathrm{~h}$ (negative feedback), followed by a positive feedback surge, reaching a maximum of $148.0 \pm 34.6 \mathrm{ng} / \mathrm{ml}$ at $24 \mathrm{~h}$. Values then declined to pretreatment levels by $56 \mathrm{~h}$. In contrast, antagonist-treated animals showed complete abolition of the expected increase at $24 \mathrm{~h}$, the low levels of the negative feedback phase being maintained for $36-72 \mathrm{~h}$.
\end{abstract}

These results show that hypothalamic LHRH release is essential during the oestrogen-induced LH surge, and that a direct oestrogen-induced component at the pituitary level is not expressed in the absence of LHRH in the marmoset.

Keywords: LHRH antagonist; LH surge; marmoset; oestrogen; ovariectomy

\section{Introduction}

In mammalian species oestradiol secretion from the developing follicle is the principal factor in inducing the preovulatory surge of luteinizing hormone ( $\mathrm{LH})$ (Ferin et al., 1974a). This surge can be mimicked during the early follicular phase, or in ovariectomized animals, by administration of oestradiol benzoate. It is also well established that pituitary gonadotrophin secretion is under the control of hypothalamic luteinizing hormone-releasing hormone (LHRH); thus, in monkeys chronically deprived of LHRH action by lesions in the arcuate nucleus (Knobil, 1980), pituitary stalk section (Vaughan et al., 1980), active immunization against LHRH (Fraser, 1983) or chronic treatment with an LHRH agonist or antagonist (Fraser, 1981; Kenigsberg et al., 1984) the oestrogen-induced LH surge was found to be prevented. However, there is evidence to suggest that, in the primate, oestrogen can have a direct stimulatory effect on the pituitary in the absence of LHRH, provided that the pituitary has been primed previously by the decapeptide.

In ovariectomized rhesus moneys with lesions in the arcuate nucleus and in which gonadotrophin release had been stimulated with exogenous LHRH pulses, an LH surge could still be induced even if LHRH treatment was stopped $24 \mathrm{~h}$ before the administration of oestrogen (Wildt et al., 1981). An LH surge was also observed if oestrogen was administered immediately after pituitary stalk section (Ferin et al., 1979). Immunoneutralization of LHRH at the time of oestrogen administration also failed to block the LH surge (McCormack et al., 1977). These results suggested 
that in primates oestrogens can induce an LH surge by acting upon an LHRH-primed pituitary without the presence of LHRH during the surge.

To define the role of LHRH during the LH surge it is important to distinguish between the effects of chronic deprivation of LHRH for several days or weeks from an interference with its action immediately before, and during the time of, the anticipated surge only. For this purpose an experimental model in which LHRH secretion is left intact until the onset of the oestrogen stimulation must be used. In the present study we have investigated the effects of blocking the pituitary LHRH receptor during the period of the expected LH surge in an ovariectomized New World primate, the common marmoset, by using an LHRH antagonist.

\section{Materials and Methods}

Animals. Six adult female marmoset monkeys weighing 250-400 g were used. The animals had been ovariectomized 6 48 months before this study. Full details of their management have been published previously (Hearn et al., 1975). Blood samples $(0.2 \mathrm{ml})$ were collected by femoral venepuncture without anaesthesia, at $6-12 \mathrm{~h}$ intervals for 3 days, into $1.0 \mathrm{ml}$ heparinized syringes. The blood was centrifuged at $1000 \mathrm{~g}$ for $20 \mathrm{~min}$ and the separated plasma was stored at $-20^{\circ} \mathrm{C}$ until assayed for $\mathrm{LH}$.

Experimental protocol. In all experiments, each monkey was given $35 \mu \mathrm{g}$ oestradiol benzoate (Sigma Chemical Company Ltd, Poole, Dorset, UK) as a single s.c. injection in $0.2 \mathrm{ml}$ arachis oil, immediately after the first blood sample was withdrawn, to induce an $\mathrm{LH}$ surge. The LHRH antagonist $\left[N\right.$-Ac-D-Nal(2) ${ }^{1}, \mathrm{D}-\mathrm{pCl}-\mathrm{Phe}{ }^{2}, \mathrm{D}-\mathrm{Trp}^{3}, \mathrm{D}-$ hArg(Et2) ${ }^{6}$, D-Ala $^{10}$ ]LHRH (detirelix: Syntex, Palo Alto, CA, USA) was dissolved in 0.9\% (w/v) NaCl: propylene glycol $(1: 1 \mathrm{v} / \mathrm{v})$ and administered subcutaneously. The 6 animals were treated with the LHRH antagonist, at a dose of $300 \mu \mathrm{g} / \mathrm{kg}$, on two separate occasions. This dose was selected on the basis of previous studies in stump-tailed and crab-eating macaques (Adams et al., 1986; Fraser et al., 1986).

In the first experiment each monkey was given LHRH antagonist at $12 \mathrm{~h}$ intervals over a $24 \mathrm{~h}$ period ( $3 \mathrm{injections).}$ In the second experiment each monkey received 2 injections of LHRH antagonist separated by a $24 \mathrm{~h}$ interval. In both experiments LHRH antagonist treatment began immediately after administration of the oestradiol benzoate. The same 6 monkeys served as their own controls and received only the vehicle at $12 \mathrm{~h}$ intervals ( 3 injections). At least 4 weeks elapsed between each set of treatments.

Measurement of $\mathrm{LH}$. LH was determined using an in-vitro bioassay based on the production of testosterone by dispersed mouse Leydig cells as described previously (Fraser et al., 1986). Sensitivity of the assay was $2 \mathrm{ng}$ LH/ml using the rhesus monkey pituitary standard RP-1, supplied by the National Institute of Child Health and Human Development, Bethesda, MD, USA. Inter- and intra-assay coefficients of variance were 15 and $11 \%$ respectively.

Statistics. Heterogeneity of variance in the concentrations of plasma $\mathrm{LH}$ was reduced by $\log$ transformation of the data. Changes in LH concentrations within each treatment group were statistically evaluated using one-way analysis of variance for repeated measures. Separate two-way analysis of variance for repeated measures was carried out on the $\mathrm{LH}$ values in control and the $12 \mathrm{~h}$ and $24 \mathrm{~h}$ interval LHRH antagonist-treatment groups. In all cases, comparisons of individual transformed means were made using Newman-Keul pairwise comparisons.

\section{Results}

All of the control monkeys showed an LH surge in response to treatment with oestradiol benzoate (Fig. 1a). Plasma concentrations of $\mathrm{LH}$ were suppressed from a control value of $30.3 \pm 5 \cdot 8 \mathrm{ng} / \mathrm{ml}$ at time $0 \mathrm{~h}$ to $12 \cdot 8 \pm 2.6 \mathrm{ng} / \mathrm{ml}$ at $6 \mathrm{~h}$ after the administration of oestradiol benzoate (negative feedback action, group mean \pm s.e.m.) This was followed by the positive feedback action or LH surge, reaching a peak value of $148.0 \pm 34.6 \mathrm{ng} / \mathrm{ml}$ (group mean \pm s.e.m.) at $24 \mathrm{~h}$, followed by a decline to basal pretreatment values by $56 \mathrm{~h}$.

The dramatic increase in plasma LH observed in the control group $24 \mathrm{~h}$ after oestradiol benzoate was completely absent from all LHRH antagonist-treated monkeys (Figs $1 \mathrm{~b}$ and $\mathrm{c}$ ). Moreover, the low levels of plasma LH seen during the negative feedback phase were maintained for at least 36-72 $\mathrm{h}$ in antagonist-treated monkeys (Figs $1 \mathrm{~b}$ and $\mathrm{c}$ ). One of the monkeys treated with LHRH antagonist at 12-h intervals over the period of $24 \mathrm{~h}$ did, however, show an LH surge at $48 \mathrm{~h}$ after receiving oestradiol benzoate which was indistinguishable, in terms of amplitude, from that seen at $24 \mathrm{~h}$ after oestradiol benzoate in the control experiment (Fig. 2). 


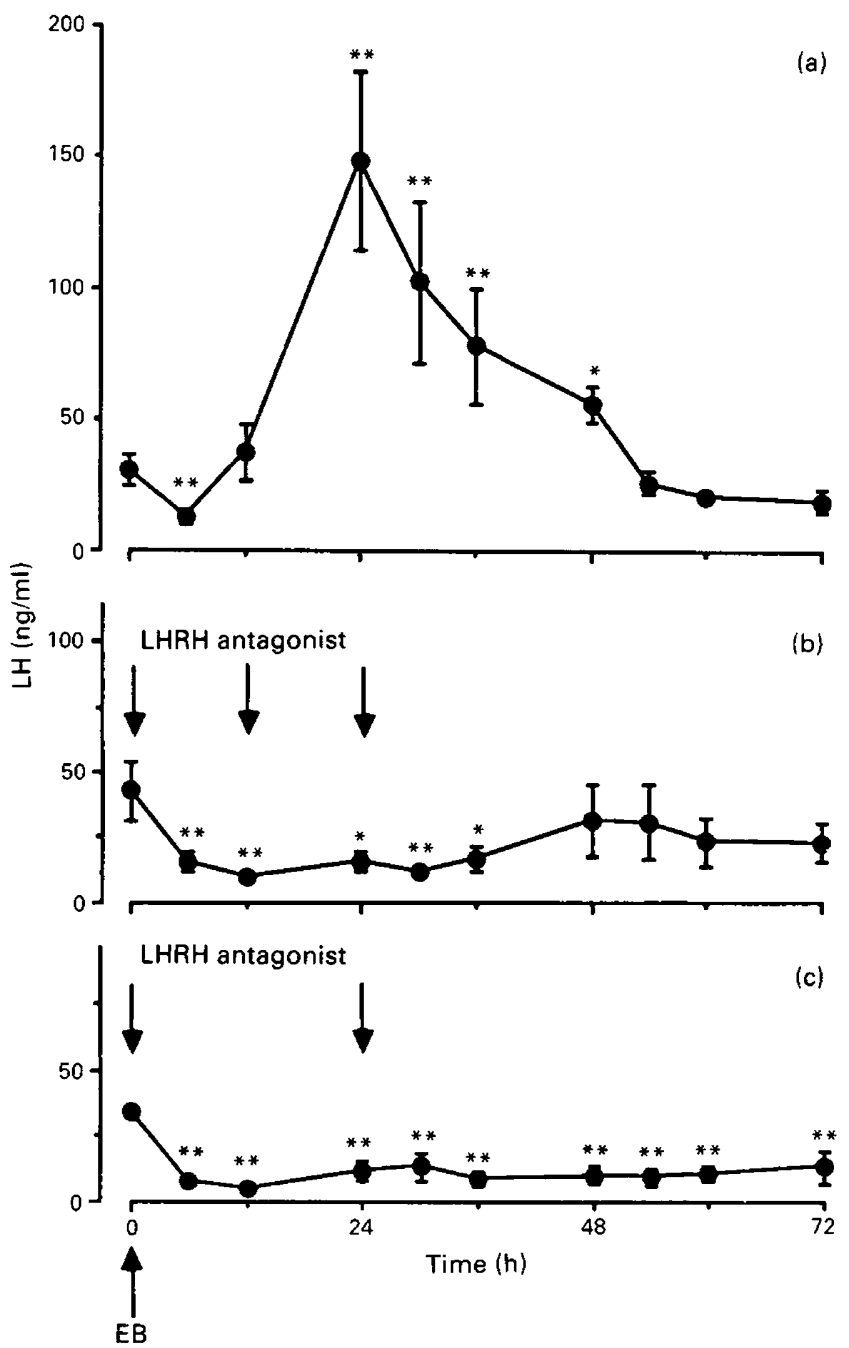

Fig. 1. The effect of an LHRH antagonist (detirelix) on plasma LH release in 6 ovariectomized marmosets. (a) Control animals received $35 \mu \mathrm{g}$ oestradiol benzoate (EB) s.c. at time $0 \mathrm{~h}$; (b) the same animals treated with $300 \mu \mathrm{g}$ deterilix/kg s.c. at $0 \mathrm{~h}, 12 \mathrm{~h}$ and $24 \mathrm{~h}$ after oestrogen administration; (c) the same animals treated with $300 \mu \mathrm{g}$ deterilix $/ \mathrm{kg}$ s.c. at $0 \mathrm{~h}$ and $24 \mathrm{~h}$ after oestrogen administration. Values are plotted as group means \pm s.e.m. ${ }^{*} P<0.05 ;{ }^{* *} P<0.01$ compared with value at $0 \mathrm{~h}$.

\section{Discussion}

Chronic deprivation of LHRH prevents the oestrogen-induced LH surge, but fails to answer the question of the specific requirement for LHRH during the surge. The present study was designed so that the LHRH antagonist was not given until the time of oestradiol benzoate administration. Even after allowing LHRH priming of the pituitary, the oestrogen-induced LH surge was completely abolished by administration of the antagonist in the marmoset, strongly indicating that in this species the continued presence of LHRH is essential for induction of the LH surge. We have also shown that treatment of an ovariectomized marmoset with a single dose of LHRH antagonist, administered at the height of the oestradiol-induced LH surge, results in a precipitous decrease in 


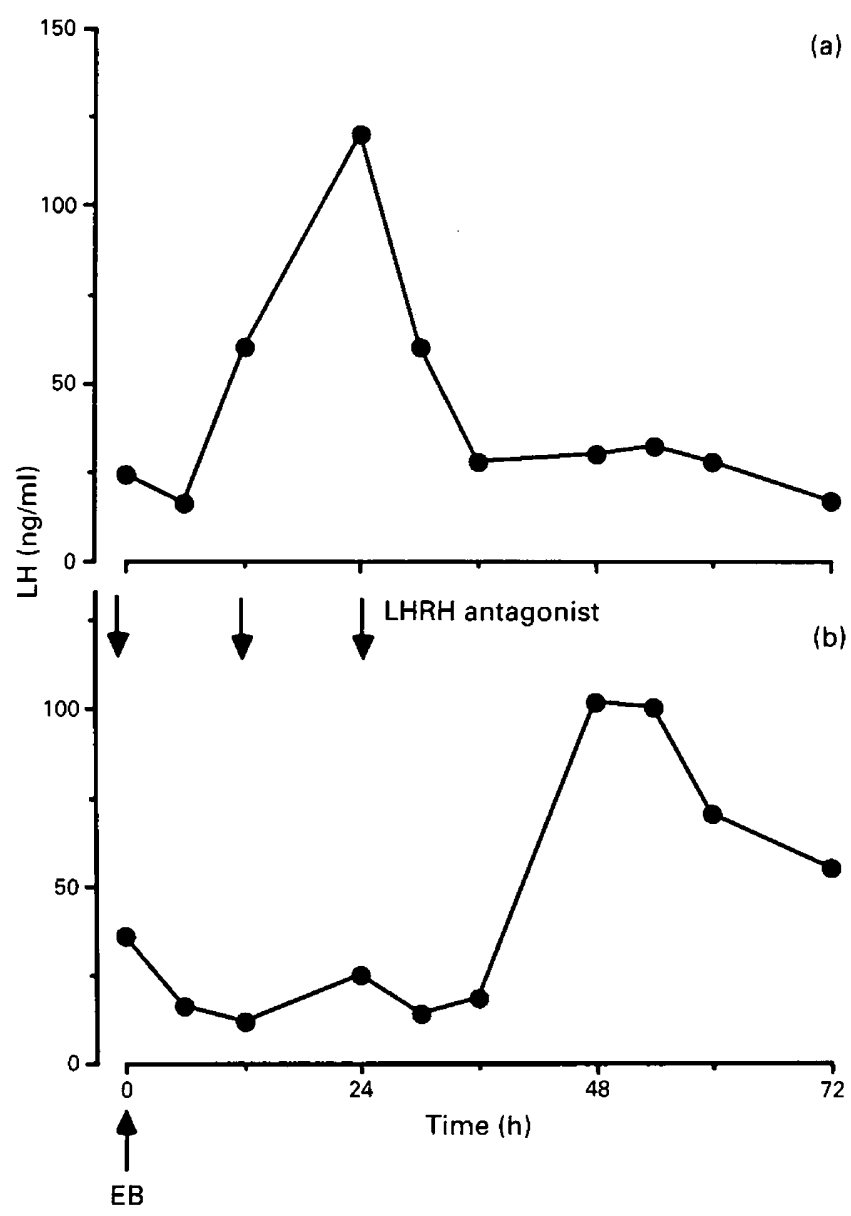

Fig. 2. The effect of an LHRH antagonist (detirelix) on plasma $\mathrm{LH}$ release in an individual ovariectomized marmoset. (a) The effect of oestradiol benzoate $(\mathrm{EB} ; 35 \mu \mathrm{g})$ at $0 \mathrm{~h}$ on subsequent release of $\mathrm{LH}$; (b) the effect of $300 \mu \mathrm{g}$ deterilix $/ \mathrm{kg}$ at $0 \mathrm{~h}, 12 \mathrm{~h}$ and $24 \mathrm{~h}$ on the $\mathrm{LH}$ response to treatment with oestradiol benzoate at $0 \mathrm{~h}$.

plasma LH concentrations to basal values (K. T. O'Byrne \& S. F. Lunn, unpublished observation). The rate of decrease was in accordance with the half-life of this hormone and this further suggests that LHRH action is a prerequisite for maintenance of the LH surge in this species.

One of the 6 animals treated with the antagonist at $12 \mathrm{~h}$ intervals showed an LH surge which was delayed until $48 \mathrm{~h}$ after oestradiol administration. An explanation for this aberrant result is difficult, but it is unlikely to be related to the dose of antagonist since the same animal did not show such a delayed response when treated with the antagonist at a $24 \mathrm{~h}$ interval. Perhaps in this instance hypothalamic LHRH release was delayed or extended so that the LH was secreted as the effect of the antagonist was declining.

Oestrogen exerts its effects at two possible sites of action in inducing the LH surge. The involvement of a hypothalamic site has been suggested by Levine et al. (1985), who, by measuring hypothalamic LHRH using the technique of push-pull perfusion, showed evidence of increased LHRH output, albeit of variable magnitude and at lower levels than might be expected from the duration of the LH surge. The rising concentrations of oestradiol during the follicular phase, or following the administration of oestradiol benzoate, result in an increase in the numbers of 
pituitary LHRH receptors (Adams et al., 1981) and an increase in gonadotroph responsiveness (Ferin et al., 1974b; Wang \& Yen, 1975; Hoff et al., 1977), and these changes are thought to be due in part to direct actions of oestrogen on the pituitary gonadotroph.

If the action of LHRH is prevented, the relative roles of the hypothalamus and the pituitary can then be investigated. The importance of a direct action of oestrogen on the pituitary is further supported by the ability of this steroid to induce an LH surge in ovariectomized rhesus monkeys with lesions in the arcuate nucleus in which gonadotrophin release had been stimulated with exogenous LHRH pulses but these had been stopped $24 \mathrm{~h}$ before the administration of oestrogen (Wildt et al., 1981). Oestrogen treatment also results in an LH surge when given immediately after pituitary stalk section (Ferin et al., 1979), or following immunoneutralization of LHRH at the time of oestrogen administration (McCormack et al., 1977). These results suggest that in primates oestrogen can induce an LH surge by acting on an LHRH-primed pituitary in the absence of LHRH stimulation during the surge.

In contrast, in the pituitary stalk-sectioned rhesus monkey with a Teflon barrier placed between the cut ends of the stalk, Norman et al. (1982) showed that ovulation could not be achieved by the administration of uniform pulses of LHRH, and suggested that an increased hypothalamic release of LHRH was required to elicit a preovulatory LH surge. Using an LHRH antagonist to achieve LHRH receptor blockade, Asch et al. (1983), and Norman et al. (1986), claim to have prevented the oestrogen-induced LH surge in ovariectomized rhesus monkeys. However, it was evident from those results that $\mathrm{LH}$ did rise during LHRH antagonist administration. While these studies with antagonist demonstrated a hypothalamic influence on the magnitude of the $\mathrm{LH}$ surge a direct effect of oestrogen still appeared to comprise a significant component of the response. Another possibility is that in earlier studies the antagonist used failed to block all of the pituitary LHRH receptors while this was achieved with detirelix; however, using this antagonist in the stump-tailed macaque, preliminary results also suggest a pituitary component in the oestrogen-induced LH surge (O'Byrne et al., 1988).

In conclusion, in both the Old and New World primate, it is likely that under physiological conditions hypothalamic LHRH is involved during the LH surge. However, in the Old World primate, most studies support an oestrogen involvement at the pituitary to induce an $\mathrm{LH}$ surge which can be expressed in the absence of LHRH. In the marmoset, we do not rule out the possibility of an oestradiol-mediated amplification of the pituitary response to LHRH upon interaction with its receptor. However, our results show clearly that the presence of LHRH is essential for induction of the LH surge and suggest that, in this New World monkey, oestradiol action on the pituitary is not expressed in the absence of LHRH.

We thank the staff of the MRC Reproductive Biology Primate Unit for care and maintenance of the animals; Dr J. J. Nestor, Jr and Dr B. H. Vickery for the gift of the LHRH antagonist; and the NICHHD for the RP-1 LH standard.

\section{References}

Adams, L.A., Bremner, W.J., Nestor, J.J., Jr, Vickery, B.H. \& Steiner, R.A. (1986) Suppression of plasma gonadotropins and testosterone in adult male monkeys (Macaca fascicularis) by a potent inhibitory analog of gonadotropin-releasing hormone. $J$. clin. Endocr. Metab. 62, 58-63.

Adams, T.E., Norman, R.L. \& Spies, H.G. (1981) Gonadotropin-releasing hormone receptor binding and pituitary responsiveness in estradiol primed monkeys. Science, N.Y. 213, 1388-1390.

Asch, R.H., Balmaceda, J.P., Borghi, M.R., Niesvisky R., Coy, D.H. \& Schally, A.V. (1983) Suppression of the positive feedback of estradiol benzoate on gonadotropin secretion by an inhibitory analog of luteinizing hormone releasing hormone (LRH) in oophorectomized rhesus monkeys: evidence for a necessary synergism between LRH and estrogens. J. clin. Endocr. Metab. 57, 367-372.

Ferin, M., Dyrenfurth, I., Cowchocks, S., Warren, M. \& Vande Wiele, R.L. (1974a) Active immunization to $17 \beta$-estradiol and its effects upon the reproductive cycle of the rhesus monkey. Endocrinology 94,765-776.

Ferin, M., Warren, M., Dyrenfurth, I., Vande Wiele, R.L. \& White, W.F. (1974b) Response of rhesus monkeys 
to LHRH throughout the ovarian cycle. $J$, clin. Endocr. Metab. 38, 231-237.

Ferin, M., Rosenblatt, H., Carmel, P.W., Antunes, J.L. \& Vande Wiele, R.L. (1979) Estrogen-induced gonadotropin surges in female rhesus monkeys after pituitary stalk section. Endocrinology 104, 50-52.

Fraser, H.M. (1981) Effect of oestradiol on gonadotrophin release in stumptailed monkeys (Macaca arctoides) treated chronically with an agonist analogue of luteinizing hormone releasing hormone. J. Endocr. 91, 525-530.

Fraser, H.M. (1983) Active immunization of stumptailed macaque monkeys against luteinizing hormone releasing hormone, and its effects on menstrual cycles, ovarian steroids and positive feedback. $J$. reprod. Immunol. 5, 173-183.

Fraser, H.M., Abbott, M., Laird, N.C., McNeilly, A.S., Nestor, J.J., Jr \& Vickery, B.H. (1986) Effects of an LH-releasing hormone antagonist on the secretion of LH, FSH, prolactin and ovarian steroids at different stages of the luteal phase in the stumptailed macaque (Macaca arctoides). J. Endocr. 111, 83-90.

Hearn, J.P., Lunn, S.F., Burden, F.J. \& Pilcher, M.M. (1975) Management of marmosets for biomedical research. Lab. Anim. 9, 125-134.

Hoff, J.D., Lasley, B.L., Wang, C.F. \& Yen, S.S.C. (1977) The two pools of pituitary gonadotropin: regulation during the menstrual cycle. J. clin. Endocr. Metab. 44, 302-312.

Kenigsberg, D., Burt, M.D., Littman, A. \& Hodgen, G.D. (1984) Medical hypophysectomy. 1. Dose-response using a gonadotropin-releasing hormone antagonist. Fert. Steril. 42, 112-115.

Knobil, E. (1980) The neuroendocrine control of the menstrual cycle. Recent Prog. Horm. Res. 36, 53-88.

Levine, J.E., Norman, R.L., Gliessman, P.M., Oyama, T.Y., Bangsberg, D.R., \& Spies, H.G. (1985) In vivo gonadotropin-releasing hormone release and serum luteinizing hormone measurements in ovariectomized, estrogen-treated rhesus macaques. Endocrinology 117, 711-721.

McCormack, J.T., Plant, T.M., Hess, D.L. \& Knobil, E. (1977) The effect of luteinizing hormone releasing hormone (LHRH) antiserum on gonadotropin secretion in the rhesus monkey. Endocrinology 100, 663-667.

Norman, R.L., Gliessman, P., Lindstrom, S.A., Hill, J. \& Spies, H.G. (1982) Reinitiation of ovulatory cycles in pituitary stalk-sectioned rhesus monkeys: Evidence for a specific hypothalamic message for the preovulatory release of luteinizing hormone. J. clin. Endocr. Metab. 111, 1874-1882.

Norman, R.L., Rivier, J., Vale, W. \& Spies, H.G. (1986) Inhibition of estradiol-induced gonadotropin release in ovariectomized rhesus macaques by a gonadotropin-releasing hormone antagonist. Fert. Steril. 45, 288-291.

O'Byrne, K.T., Lunn, S.F. \& Fraser, H.M. (1988) Effect of LHRH antagonist on oestradiol-induced $\mathrm{LH}$ surges in non-human primates. J. Reprod. Fert. Abstr. Ser. 1, 7.

Vaughan, L., Carmel, P.W., Dyrenfurth I., Frantz, A.G. \& Ferin, M. (1980) Section of the pituitary stalk in the rhesus monkey 1. Endocrine studies. Neuroendocrinology 30,70-75.

Wang, C.F. \& Yen, S.S.C. (1975) Direct evidence of estrogen modulation of pituitary sensitivity to luteinizing hormone-releasing factor during the menstrual cycle. J. clin. Invest. 55, 201-204.

Wildt, L., Hausler, A., Hutchison J.S., Marshall, G. \& Knobil, E. (1981) Estradiol as a gonadotropin releasing hormone in the rhesus monkey. Endocrinology 108, 2011-2012.

Received 1 August 1988 